DOI: $10.17516 / 1997-1370-0228$

УДК 2-535.5

\title{
Standing at the Cross. Stabat Mater. The Cantata of the Composer Metropolitan Hilarion (Alfeyev). Theme and Its Analysis
}

\author{
Vera P. Lozinskaya* \\ Siberian Federal University \\ Krasnoyarsk, Russian Federation
}

Received 11.12.2017, received in revised form 26.01.2018, accepted 06.02.2018

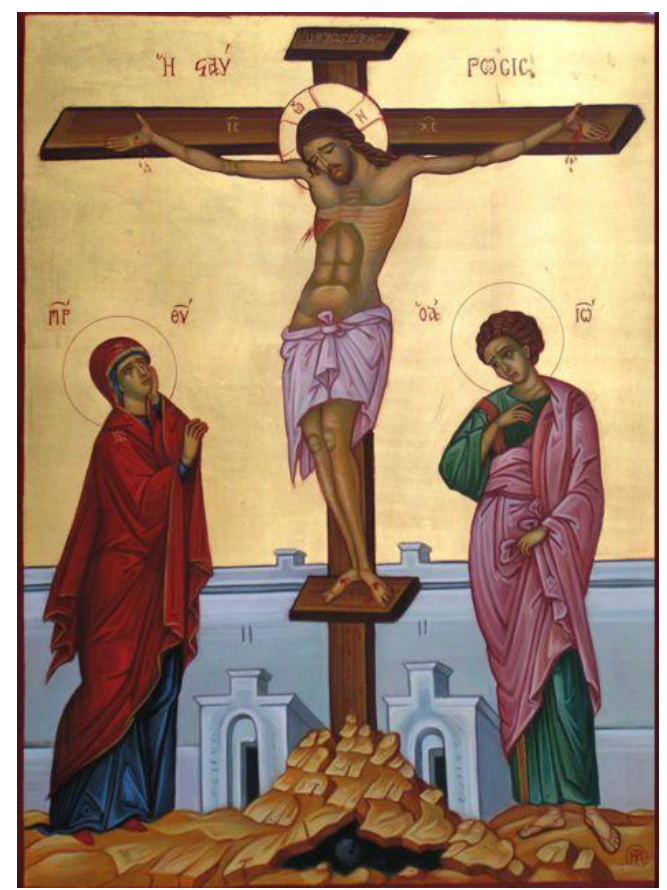

Icon "The Standing of the Mother of God at the Cross"

\begin{abstract}
The $20^{\text {th }}$ century is marked with the discoveries in all the areas of the Slavic peoples' culture that antiquity and value of contribution to the world culture deserves thorough studying. Outstanding masters of the $20^{\text {th }}-21^{\text {st }}$ centuries in their creative work and in their compositions turned to the genres of the Western European music of the Baroque and Classicism (oratorio, cantata, big concert, sonata, quartet and romance).
\end{abstract}

(C) Siberian Federal University. All rights reserved

* Corresponding author E-mail address: vera.lozinskaya@mail.ru 
At the same time, their reliance upon the achievements of the Russian musicians of the $19^{\text {th }}$ century is evident. The composers' works are characterized by the expansion of the lexical basis of the musical language, the use of folklore and introduction of the modern techniques of the composers' writing.

The creative work of Metropolitan Hilarion (Alfeyev) is a unique phenomenon in the history of the world and Russian musical culture of the late $20^{\text {th }}$-early $21^{\text {st }}$ century.

The cantata Stabat Mater for soloists, choir and orchestra is studied in this article.

The relevance of the musical compositions by Hilarion Alfeyev lies in the fact that most of them are based on the religious themes and Christian texts. Great ideals and the images of Jesus Christ and the Virgin found a perfect and convincing embodiment in his music. Centuries-old traditions of the cultural and spiritual life of Russia have been preserved and developed in the cantata Stabat Mater.

The value of his compositions is in a strong connection with the achievements of the outstanding composers of the $18^{\text {th }}-20^{\text {th }}$ centuries, as well as in the multilateral implementation of intonations and rhythms of the Western European music and Russian folklore combined with church hymns.

The music of composer Hilarion (Alfeyev) is bright, powerful and rigorous, but at the same time it is distinguished by the subtlest lyricism. It became a revelation of not only the art of its country, but of the whole world. His compositions penetrate a human soul; they are clear and accessible to everyone.

Keywords: spiritual music culture, cantata, medieval Catholic sequence, polyphony, passacaglia, Russian folk songs.

Research area: culturology.

Citation: Lozinskaya V.P. (2018) Standing at the cross. Stabat Mater. The cantata of the composer metropolitan Hilarion (Alfeyev). Theme and its analysis. J. Sib. Fed. Univ. Humanit. Soc. Sci., 15(4), 485-493. DOI: 10.17516/1997-1370-0228

But above all these things put on love, which is the bond of perfection

And let the peace of God rule in your hearts...

(Col. 3, 14-15)

\section{Introduction}

For centuries, hundreds of thousands of spiritual songs have been accumulated in Russia. Their authors were both eminent composers, and unknown anonymous regents. Spiritual and musical art of the turn of the $20^{\text {th }}$ and the $21^{\text {st }}$ centuries is impressive by the variety of forms and genres. The works of some composers are designed to preserve and continue the church-singing tradition. The compositions of other authors also carry out an educational function: involving listeners to the high spiritual and moral ideal.

Ancient Rus', Holy Rus', Great Russia! This is how we call our country. The ancient
Russian state, the center of which was in Kiev, arose in the middle of the $9^{\text {th }}$ century. The adoption of Christianity in Russia in the late $10^{\text {th }}$ century was an important historical event, which contributed to strengthening the state unity of Kievan Rus' and its culture development.

The fate of Russia and its people is difficult and interesting. How did it survive during the years of war, starvation, devastation and repressions? It is amazing! It is held by prayers, by the Orthodox Faith and the Protection of the Blessed Virgin Mary! Russia is Her home!

Since ancient times, Russian people perceive Rus' "as the home of the Most Holy 
Mother of God". The faithful Russian princes turned to Her for help when they went to the battlefield and proclaimed: "For our Lord the Savior and for the Blessed Virgin Mary, and for the home of the Most Pure Virgin" (Fast, 2010).

In the history of the Church, information about the Mother of God was compiled bit by bit. Who is She for us? What is Her role in the life of the Savior? Temples are constructed, icons are painted and musical compositions are created in the honor of the Queen of Heaven.

She is called Virgin Mary, Ever-Virgin, the Mother of God, Our Lady, the Queen of Heaven, the Mother of God, the More Honorable than the Cherubim and Beyond Compare more Glorious than the Seraphim, the Wife, the Most Holy Mother of God...

The Mother of God is loved, but of course, after God. And she is the closest from all of us to the Savior. For Christians the Queen of Heaven is the Mother, and all over the world they turn to Her for comfort and help.

The number of icons of the Mother of God throughout the world reaches several hundreds. "In Russia the icon performed a very special function - it was the image for praying and a book for studying, a companion of life and a shrine, the main treasure that was inherited from generation to generation" (Yazykova, 1995).

The icons of the Most Pure Virgin Mary, sent by the forces above, are scattered "across the face" of our homeland, forming the Heavenly Protection. Russia is protected by a specific Cross of Her five wonder-working icons. The countries' northern limits (the borders of the country) are under the Protection of the Tikhvin Icon of the Mother of God, the southern ones are under the Protection of the Iberian Icon and the western ones are under the Protection of the Smolensk Icon. The ancient Vladimir holy image protects and blesses the center of Russia, and the miraculous Kazan Icon of Our Most Pure Mother is shining with the rays of grace in the east.

A little is said about the Mother of God in the four Gospels. The narration of the Virgin Mary is found in the Gospel of Luke - 1:1825 - the Prediction of the Nativity of John the
Baptist; 1:26-38 - Annunciation of the Angel Gabriel to the Blessed Virgin Mary about the birth of Christ; 1:39-56 - Mary in the house of Elizabeth (Her relative); 1:46-55 - "My soul magnifies the Lord ..." (Magnificat, from the Latin magnifico - "exalt", "glorify"). In the same Gospel of Luke in the second chapter in 2:1-7, the birth of Jesus Christ is narrated; 2:820 is the appearance of the Angel of the Lord to the shepherds; $2: 21-35$ - the meeting of the righteous Simeon the God-Receiver with the Infant Jesus in the Temple of Jerusalem (the Presentation of the Lord); 2:39-40 - about returning to Nazareth; 2:41-52 - annual visit to Jerusalem on the feast of Easter.

The Mother of God is mentioned in the Gospel of John: 2:1-12 - the first miracle, worked by Jesus Christ at Cana in Galilee. In the text of the Gospel of Matthew: 12:46-50 the Mother and brothers of Jesus, as well as in the Gospels of Mark 3:31-35 and Luke 8:19-21 it is written "Here are My Mother and My brothers". In the Gospels of Luke 23:27-31 - the weeping of the daughters of Jerusalem when Jesus is led to the Cross. "It should be noted that Mary is not mentioned here, but, according to the church tradition, She, nonetheless, was present at that. In Jerusalem, the pilgrims are shown one of the fourteen stops on the way of the Savior, where He met with the Mother" (Fast, 2010).

In the Gospel of John 19:25-27, Mary is at the Cross, and Jesus, seeing the Mother and the disciple whom he loved standing here, says to his Mother: "Woman! Behold, your son". Then He says to the disciple: "Behold, your mother!" From that time on, this disciple took her into his home".

"Women observe the burial of the Savior, performed by Joseph of Arimathea and Nicodemus (John 19:38-42). And again, according to the church tradition, Mary is at the burial ... but nothing is said about this in the Gospel, there are only the words of Jesus to the Mother and John the Evangelist" (Fast, 2010).

"Then the Evangelists Matthew, Mark, Luke and John narrate about the myrrh-bearers: Mary Magdalene, Maria the wife of Cleop(h) and the other Mary. The interpreters usually understand the "other Mary" as the Mother 
of God, but there is no unanimity of opinions. Seemingly, the Mother of Jesus was there, although it does not follow directly from their evangelical text" (Fast, 2010).

"Finally, the last text, this time not from the Gospel: Acts 1:14 - the Ascension of Jesus Christ. Mary, the Mother of the Lord, is directly mentioned among the women who were at the Ascension. In Russian iconography of the Ascension, She is always placed in the center of the image, and the apostles are next to Her" (Fast, 2010).

The fact that the Holy Mother stood at the Cross on which Christ was crucified is mentioned only in the Gospel of John.

On that far from our time and terrible Day, the Spear pierced Christ and the soul of His Mother with Him (Fig. 1). There is an icon of the Mother of God, which is called Seven Blades. This icon depicts seven blades piercing Her (the icon has another name - Simeon Pronounces).

The Mother's grief was immeasurable, holy and silent. The Mother's sorrow for the Son, the sorrow of the Mother of God. The Holy Church reveals the mystery of the sufferings of the Mother of God.
In the $10^{\text {th }}$ century, the Byzantine poet Symeon Metaphrast wrote the canon To the Weeping of the Virgin, which is read at the Compline on Good Friday. The poet emphasized that the Son of the Mother of God is God Incarnate, and She understands this.

In the Orthodox Church on Great Friday the Gospel of John is read when the completion of the earthly life of Christ is narrated. At the end of the Great Vespers the Shroud is taken out and the Supplicatory Canon To the Weeping of the Virgin is sung.

Tears streamed uncontrollably from the eyes of the Mother of God. She understood that the Son went to the crucifixion voluntarily to take all the sins of the world upon Himself in order to reconcile man with God. He fulfilled the will of His Heavenly Father. There are following lines in the Supplicatory Canon:

"Oh, how did the depth of mercy hide from You?", said the Lord secretly to the Mother. "As wishing to save My creation, I decided to die; but I will rise again and glory thee, as the Lord of heaven and earth".

On the Great Saturday, instead of the Cherubic Hymn, Let All Human Flesh be Silent ... and instead of Axion Estin..., the irmos of the

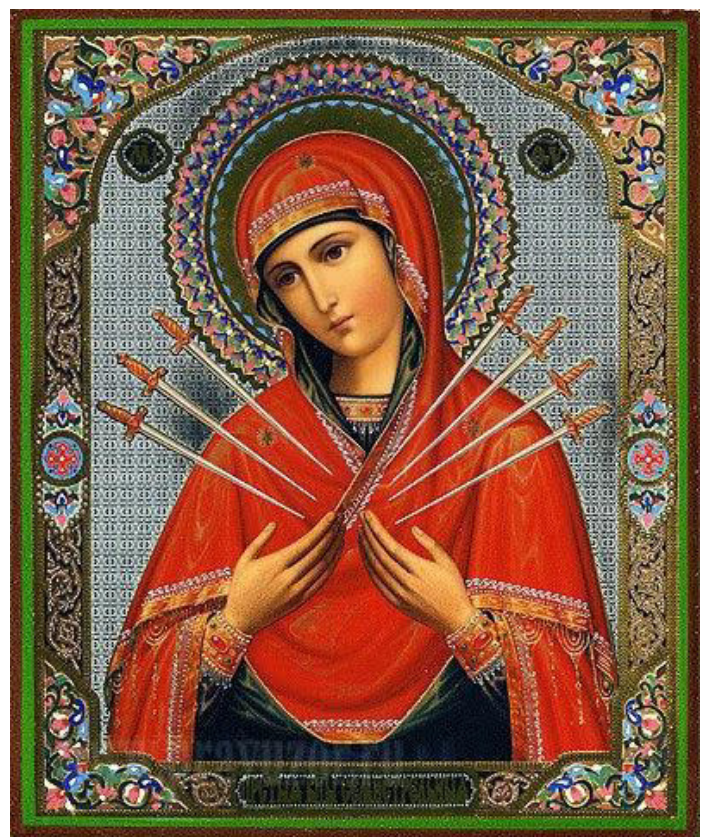

Fig. 1. The Icon of the Mother of God of Seven Blades 


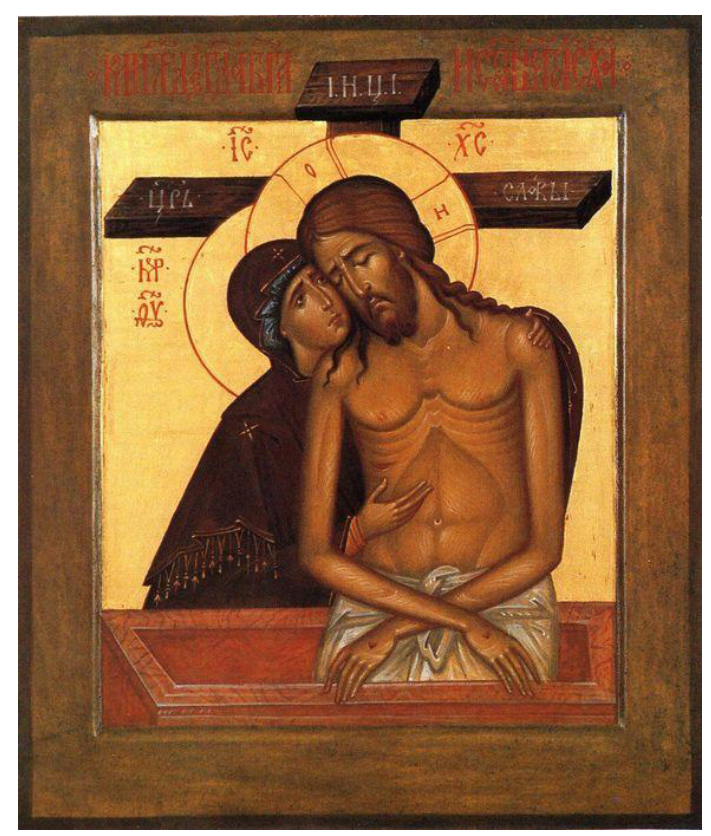

Fig. 2. Icon of the Mother of God Weep Not for Me, o Mother

ninth song of the canon of Kosma Mayumsky "Weep not for Me, o Mother, seeing in the tomb the Son, the Son was conceived in the womb without the Seed: as I will rise up and be glorified, and I will be unceasingly exalted with glory, as the God, magnifying You through faith and love" is sung in the church. The Hymn is sung in the name of the Savior who comforts His Mother. He speaks of His Resurrection that overcomes death. This is the culmination of the content of the entire Great Week: sorrow and the expectation of joy (Yazykova, 2016) (Fig. 2).

\section{Stabat Mater \\ cantata for soloists, choir and orchestra}

Hilarion - secular name Grigory Valerievich Alfeyev - an outstanding personality in the history of the Russian Orthodox Church and contemporary music. He was born in the Moscow intelligentsia family on July 24, 1962. The music classes began from his early childhood. Then he studied at the Gnesin Moscow Secondary Specialized Music School in the class of violin, and in V.B. Dovgan's class in composition for eleven years. After finishing mu- sic school he entered the Moscow Tchaikovsky Conservatory to the composition department (the class of Professor A.A. Nikolaev).

At the age of 21, Gregory took monastic tonsure with the name of Hilarion, and the whole further life of the present Metropolitan is connected with the ministry to the Church.

At present, Metropolitan Hilarion of Volokolamsk is a well-known Theologian, Church historian, the chairman of the Department for External Church Relations of the Moscow Patriarchate, the permanent member of the Holy Synod, the rector of the All-Church Ss Cyril and Methodius School of Post-Graduate and Doctoral Studies. Since 2009 Metropolitan Hilarion is the Rector of the Moscow Church of the Icon of the Mother of God 'Joy of All Who Sorrow' on Bolshaya Ordynka.

Metropolitan Hilarion is the author of eight hundred publications, including more than twenty monographs. Before his fiftieth birthday, he completed a long-term work consisting of six volumes: Jesus Christ. Life and Teaching, that has already been published.

The authorial programmes on television: The Church and the World, A Man Before God and the series of documentaries: Holidays and 
The Church in History are of great importance in Hilarion (Alfeyev)'s life.

Metropolitan Hilarion is the member of the Composers Union of Russia. Great is his merit in creating films about the spiritual compositions of Western European and Russian composers: Bach, Mozart, Vivaldi, Haydn, Pergolesi, Tchaikovsky and Rachmaninov.

The ministry to the Church suspended the connection of the clergyman with the music for a long time. Twenty years later he returned to it. In 2006-2007, he started composing again. Such grandiose compositions as The Divine Liturgy, The Night-Long Vigil, The St Matthew Passion, The Christmas Oratorio and Stabat Mater were composed. Concerto Grosso (2012) and Fugue on the theme BACH (2012) appeared later.

All the activities of the clergyman-composer Hilarion Alfeyev are the preaching the teachings of Jesus Christ and helping people in the knowledge of God. But he emphasizes his main purpose: "First of all, I am a clergyman. And with my creative work, whether it is music, translations or books, I try to testify about Christ, to bring the word of God and His beauty to the human heart".

A brief mention of the standing of the Mother of God at the Cross in the text of the Gospel of John inspired about two hundred composers of different eras from Josquin Desprez and Palestrina, E. Astorg and G. Pergolesi, A. Vivaldi and J. Haydn, G. Rossini and A. Dvorak, G. Verdi and F. Poulenc to A. Part and A. Kiselev to create highly artistic music compositions about the sufferings of the Mother of God. Metropolitan Hilarion (Alfeyev) has also addressed this theme.

The composer created the cantata Stabat Mater during the same period as The Divine Liturgy (2006); The Night-long Vigil (2006); The St Matthew Passion (2006); The Christmas Oratorio (2007) and The Song of Ascent (2008).

Cantata (from Italian cantare - to sing) is a small vocal piece. It appeared in Italy almost simultaneously with the opera at the turn of the $16^{\text {th }}-17^{\text {th }}$ centuries. By the late $17^{\text {th }}$ century, certain features that entwined a cantata with an oratorio, where the choir was the "leading character" arose. The general forms: recitatives, arias, choirs and vocal ensembles were outlined as well. Two types of cantatas were widely spread: spiritual (on the basis of biblical stories) and secular.

In the $19^{\text {th }}-20^{\text {th }}$ centuries, the cantata was developing as a multi-part vocal and symphonic work. The terms "cantata" and "oratorio" can be equally applied to many compositions of modern music.

In the process of work on the The St Matthew Passion, Metropolitan Hilarion had an idea about creating a new composition, connected with the oratorio: to reveal the image of the Mother of God and Her suffering when She was standing at the Cross, in music.

In its philosophical depth the cantata Stabat Mater ranges with the tragedies by William Shakespeare, S. Bach's Masses and V.A. Mozart's Requiem. A special attitude to the theme determined the appearance of an unusual genre idea. The composition combines the features of cantata, oratorio, opera aria and symphony.

The Chairman of the Department for External Church Relations of the Moscow Patriarchate Metropolitan of Volokolamsk and composer Hilarion said: "Evangelist Matthew does not say anything about the standing of the Mother of God at the Cross. And I wanted to write a composition dedicated specifically to this theme. Because the theme of the mother, crying for the suffering of her child, and the theme of the Mother of God, who cries for the suffering of the whole world, and turns to her Son, incarnate God with the prayer, are the eternal themes".

"The first part of the medieval praying Stabat Mater tells about the suffering of the Virgin at the Cross, and the second one about the sinner's prayer for forgiveness and the salvation of his soul", explained the Metropolitan (Maga, 2012).

Stabat Mater is a medieval sequence (Latin sequentia - follow-up), preserved in the Catholic church singing. The full text consists of twenty three-line stanzas. It was destined for the holiday of the Seven Sorrows of the Virgin (September, 15) (Music Encyclopedia, 1985).

The libretto is based on the canonical text in Latin, which belongs (presumably) to the 
Italian poet of the Middle Ages (the $13^{\text {th }}$ century) Jacopone da Todi.

The cantata Stabat Mater was composed by Metropolitan Hilarion in 2011, and consists of four parts. "Two of them have already existed for some time as separate orchestral pieces", the author said. "One of them, a fugue for the orchestra in twelve minor keys, was called Memento". It was included into the Stabat Mater as the second part. The other piece of music that was included into the aforementioned composition as a half of the fourth part was also an orchestral piece and was called Perpeto Mobile. The remaining parts joined this core of composition" (Alfeyev, 2015).

The cantata Stabat Mater for the choir soloists and orchestra:

- Stabat Mater (the Mother stood); gin);

- Virgo Virginum (the Most Holy Vir-

- Sancta Mater (the Holy Mother).

Christ was doomed to suffer for us, the mankind. People who do not follow His great Teaching faithfully will go through a lot of sufferings in their lives.

"Unfortunately, today the sermon about Christ is not very often heard in public space. Although this is the most attractive image that we can give to people - the image of the Man who lived on earth, Who gave us an example of how we should live, the Man who was the incarnate God Himself" (Alfeyev, 2017).

The Mother of God is the symbol of all-embracing love to the Son and to all the mankind. And while Christ left us the Ten Commandments, then the Mother of God left only one: "Do whatever He tells you" (John 2:5).

\section{Conclusions}

Creative works of the clergyman-composer of global importance Metropolitan Hilarion (Alfeyev) holds a specific place in the Russian culture of the $20^{\text {th }}$ and $21^{\text {st }}$ centuries. He preserved the connection with the compositions of the masters of musical art (S. Bach, A. Vivaldi, F. Schubert, S. Prokofiev and D. Shostakovich). The unique and diverse style of the composer's musical writing is based on the achievements of Western European art, intonations and rhythms of Russian national folklore and Russian chants.

There is no single musical style in the composer's works. His choice is connected with the content of the text or with the embodied idea. The compositions of the Metropolitan-composer are distinguished by the elements of minimalism and a great "simplicity" in the choice of means of musical expressiveness.

All the parts of the cantata Stabat Mater start with orchestral episodes that, in general, represent a separate symphony in the genre of

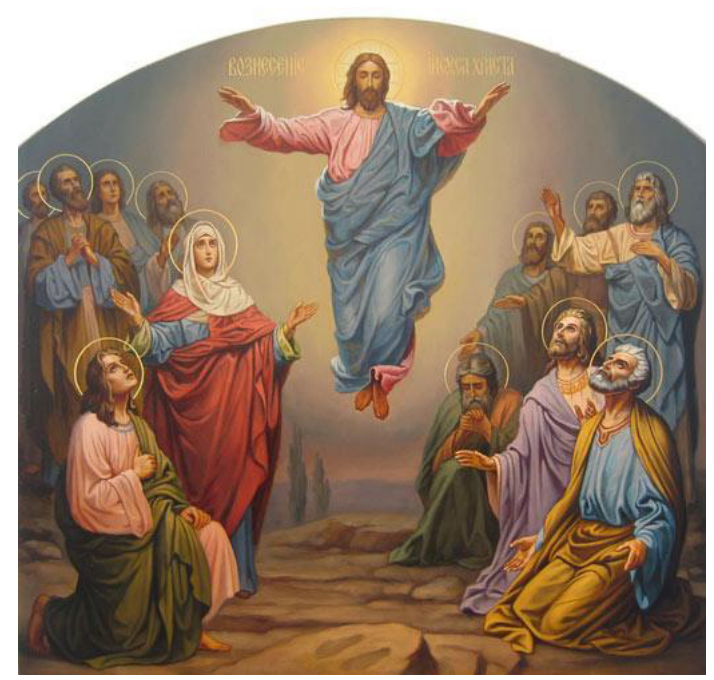

Fig. 3. Icon of the Ascension of the Lord 
cantata. The great and varied orchestra performs both an independent and accompanying role. The choir reveals the content of the composition.

The composer in his work refers to the musical forms of the West European Baroque era. So, it is passacaglia in the first part and double fugue (two themes) in twelve minor keys in the second one.

One of the themes of the double fugue which received a new development, sounds in the solo soprano (third part), the intonations of Russian folklore and church hymns can are heard in it.

In Perpeto Mobile (a fast-paced piece of music with a persistently repeated motif), music goes in a continuous and unified rhythm, with increasing dramatic tension, leading to the climax of the whole composition.

The cantata Stabat Mater by Metropolitan Hilarion is full of bright contrasts, severe restraint, significant self-centration and lyrics. The music is inspired by the spirit of mournful and philosophical reflections. It is characterized by an impressive and dramatic power. Along with The Christmas Oratorio, The Night-long Vigil and The St Matthew Passion, the cantata occupies one of the important places in the spiritual life of the $21^{\text {st }}$ century.

This composition is intended for concert performance. The premiere took place on January 22, 2012 at the Moscow International House of Music at the closing of the Second Christmas Festival of Sacred Music.

The music by Metropolitan-composer Hilarion attracts a lot of Western European and Russian professional groups, conductors and, most importantly, thousands of listeners. His creative work is devoted to the assertion of high ideals.

"I am repeatedly convinced that the language of music gives people an opportunity to communicate at the depth where words are no longer needed. And music is a very significant bearer of the evangelism that the Church is carrying today" (Alfeyev, 2015).

\section{References}

Alfeyev, H. (2015). "Stabat Mater" Mitropolita Ilariona (Alfeyeva) [Stabat Mater by Metropolitan Hilarion (Alfeyev)]. Available at: http://www.liveinternet.ru/community/4989775/post358790282 (accessed 08 April 2015).

Alfeyev, H. (2017). O mire [About the World]. Available at: http://www.hilarion.ru/video/ (accessed 21 August 2017).

Maga, A. (2012). V Moskve sostoialas' mirovaia prem'era "Stabat Mater" mitropolita Volokolamskogo Ilariona [World Premiere of Stabat Mater by the Metropolitan of Volokolamsk Hilarion Took Place in Moscow]. Available at: http://e-vestnik.ru/news/v moskve sostoyalas 4203 (accessed 23 January 2012).

Musykal'naia entsiklopedia [Music Encyclopedia] 1985. (5), 248.

Tkachev, A. (2012). Uspenskii post: khristiane protiv filosofov [Assumption Fast: Christians Versus Philosophers]. Available at: http://radonezh.ru/monitoring/uspensky-post-khristiane-protiv-filosofov-protoierey-andrey-tkachev-pravoslavie-i-mir-20643.html (accessed 15 August 2012)

Fast, G. (1994). Svet i teni Golgofy [Light and Shadows of Calvary]. Krasnoyarsk, 200.

Fast, G. (2010). Kto ona dlia nas? [Who Is She For Us?]. Moscow, 144.

Yazykova, I.K. (1995). Bogoslovie ikony [Theology of the Icon]. Moscow, 368.

Yazykova, I. (2016). "Ne rydai Mene Mati" (Oplakivanie Khrista) ikona Bozhiei Materi ["Weep Not for Me, o Mother" (The Lamentation of Christ) Icon of the Mother of God]. Available at: http://www.vidania.ru/icony/icon_ne_rydai_mne_mati.html (accessed 01 November 2016). 


\title{
Стояние у креста. «Stabat Mater».
}

Кантата композитора-митрополита

\section{Илариона (Алфеева). Сюжет и анализ}

\section{В.П. Лозинская}

Сибирский федеральный университет

Российская Федераиия, Красноярск

\begin{abstract}
Аннотация. В XX столетии происходили открытия во всех областях культуры славянских народов, древность и богатство вклада которых в мировую культуру заслуживает пристального изучения. Выдающиеся мастера XX-XXI веков в своём творчестве обращались к жанрам западноевропейской музыки эпохи барокко и классицизма (оратория, кантата, большой концерт, соната, квартет, романс). Вместе с тем заметна их опора на достижения отечественных музыкантов XIX столетия. Произведениям композиторов свойственны расширение лексической основы музыкального языка, использование фольклора, внедрение современной техники композиторского письма.

Творчество митрополита-композитора Илариона (Алфеева) - самобытное явление в истории мировой и отечественной музыкальной культуры второй половины $\mathrm{XX}$ - первой половины XXI веков.

В данной статье рассмотрена кантата «Stabat Mater» для солистов, хора и оркестра. Актуальность музыкальных сочинений Илариона Алфеева состоит в том, что большинство из них написаны на религиозные сюжеты, христианские тексты. Великие идеалы и образы Иисуса Христа и Богородицы нашли в его музыке совершенное и убедительное воплощение. В кантате «Stabat Mater» сохранены и получили новое развитие многовековые традиции культурной и духовной жизни России.

Ценность его произведений в прочной связи с достижениями выдающихся композиторов XVIII-XX века, а также в многостороннем претворении интонаций, ритмов западноевропейской музыки и русского народного фольклора в соединении с церковными песнопениями.

Музыка композитора Илариона (Алфеева) яркая, могучая, суровая, в то же время её отличает тончайший лиризм. Она стала откровением искусства не только своей страны, но и всего мира. Его сочинения проникают в душу человека, они для всех и для каждого понятны и доступны.
\end{abstract}

Ключевые слова: Россия, икона, духовная музыкальная культура, кантата, средневековая католическая секвенция, полифония, пассакалия, русская народная песенность.

Научная специальность: 24.00.00 - культурология. 